educational work which such a survey might carry on. To a librarian, his statements are of more than casual interest. $\mathrm{He}$ called attention to the dearth of popular literature on certain scientific subjects, especially geology. While other branches of nature study, including plant and animal life, appeal to a wider circle, and have been considered in a large number of interesting and attractive books, the same is not true of geology or of some of the smaller forms of animal life, as, for example, insect and fresh water life.

May I venture to call the attention of some scientists who read your journal to the desirability of some small, well-illustrated and attractively written books on geology, both descriptive and historical; on some of the mineral products, such as iron and steel; on pond life; on microscopy; and on the lives of American scientists and scientific explorers.

A book is now in preparation for publication by Scribner's, "The strange adventures of a pebble." From the announcement, this is doubtless the sort of book which has been needed for some time. In the quarterly booklist of the Pratt Institute Library (which library has made a speciality of literature in this field) for January, there is a carefully selected "List of technical and scientific books for boys." Astronomy is pretty well covered. A fairly good boys' book on chemistry was published in 1918. The two titles on geology are those by Heilprin and Shaler, both rather old; and on physics, nothing better than a reprinted edition of Hopkins, "Experimental science," which could very well be entirely revised or even broken up into two less expensive volumes. Certainly there is need for more books of this sort.

In the same line, may I call attention to the need of having books lists, to be distributed through schools and libraries and printed in an attractive style with an-illustrated cover, and giving descriptions of the books? The attention of many young people could be called to science as a life career if means like these were adopted. Another device to this same end would be a series of posters or printed reproductions of exhibits, showing some of the interesting phases of nature study or science. These could be printed by such a central bureau or by some national scientific society and distributed to be shown in schools and libraries and at Boy Scout and Camp Fire Girls headquarters.

The Youngstown Publio Library

$$
\text { JOSEPH L. WHEELER }
$$

\section{RULES OF THE INTERNATIONAL COMMISSION ON ZOOLOGICAL NOMENCLATURE}

IN reference to the applications made to the International Commission on Zoological Nomenclature for copies of the rules, the secretary desires to state that the commission has no supply of reprints for distribution. Several years ago, at request of the secretary, Mr. John Smallwood, 524 Tenth St., N. W., Washington, D. C., prepared several hundred mimeographed copies and he still has about 100 on hand. These are sold at a nominal price to cover expense of mimeographing and postage and zoologists desiring copies can obtain them, as long as the supply lasts, by applying directly to Mr. Smallwood.

C. W. Stiles, Secretary

\section{SPECIAL ARTICLES}

\section{ECHINODERMS IN BIRDS' STOMACHS}

Through the courtesy of Mr. E. W. Nelson, chief of the Bureau of Biological Survey, Washington, four vials containing echinoderms taken from birds' stomachs have been sent to me for examination. As I think there are no published records of birds' using echinoderms for food, Mr. Nelson has kindly consented to my stating in ScIence the facts revealed by this trivial investigation and certain important inferences which may be made.

Two of the vials contained holothurian-like objects taken from the stomachs of gulls. The appearance and condition of these specimens indicate that they were picked up on the beach dead and more or less damaged. As they are now quite decalcified, they are hopelessly unidentifiable, and it is probable that one at least is not a holothurian. 
The contents of the other two vials are of much greater interest. In each case, the material was taken from the stomach of a duck collected at Bayou Labatre, Alabama. One vial contains two small brown holothurians, somewhat damaged but with the calcareous particles in the skin not at all corroded or injured in any way. The condition of these specimens leaves no doubt in my mind that they were swallowed alive by the duck and that they had been in the stomach of the bird but a short time when the duck was taken. These holothurians are unquestionably some species of Thyone, and are very near, if not identical with, Thyone scabra Verrill, of the southern New England coast But Thyone scabra is not known from south of Delaware or from water less than ten fathoms deep. No holothurians of any sort are recorded from the Alabama coast. This duck's stomach therefore reveals the interesting fact that a species of Thyone, possibly scabra but probably distinct, lives in shallow water on the Alabama coast and serves as a part of the diet for bottom-feeding ducks.

The contents of the fourth vial confirms this conclusion and reveals further the notable fact that brittle-stars also serve as food for ducks. The material in this case is in very bad condition and is more or less digested, but the calcareous particles in the fragments of a holothurian indicate it is the same Thyone as in the other vial, though it has quite lost its pigmentation. Besides these Thyone fragments there are numerous armplates of a brittle-star. These are however, beyond identification and one can not even guess the genus, which they represent. The brittle-star was however an individual of moderate size and was certainly not the small and well-nigh ubiquitous Amphipholis squamata. No brittle-star is as yet recorded from the Alabama coast. It is to be hoped that the publication of the results of the collecting done by these two ducks may lead to equally effective efforts by some zoologist on the Gulf Coast.

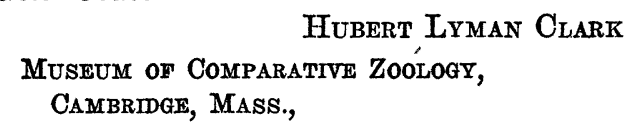

THE AMERICAN PHILOSOPHICAL SOCIETY. II

Morning Session-10 o'clock

Arthur A. Noyes, Se.D., LL.D., Vice-president, in the chair

The components and colloidal behavior of protoplasm: D. T. MacDougal, Ph.D., LL.D., director of the Desert Laboratory, Carnegie Institution, Tucson, Arizona, and H. A. SpoeHr. The living matter of plants is composed chiefly of mucilages and albuminous compounds in varying proportions mixed in the form of an emulsion or as a jelly. The molecules of solid matter are aggregated into groups which also include a number of molecules of water. Growth consists of the absorption of additional water to these groups, with more solid material being added at the same time, the process being termed hydration. The resultant increase may be detected by determination of increased dry weight, or measured as increase in length, thickness or volume. More exact studies in growth have become possible by the establishment of the fact that mixtures of 25 to 50 per cent. mucilage and 50 to 75 per cent. albumin show the hydration reactions of cell-masses of plants. It is also found that certain amino-compounds, such as histidine, glycocoll, alanin, and phenyl-alanin which are known to promate growth also increase the hydration of the biocolloids as the above mixtures are called. Following these empirical tests which have defined the character and field of research upon growth, measurements are now being made of the action of various ions or substances upon the components of protoplasm. Thus the strong metallic bases, potassium, sodium and lithium, exert a limiting action on hydration of carbohydrate (agar) in hundredth normal solution according to their position in the electromative series, potassium being the strongest and reducing swelling most. Rubidium, however, did not take its place at the head of the list in the single series of tests made, for reasons we are not able to describe. At dilute concentrations $(0.000,1 \mathrm{~N})$ all these bases promote hydration, an effect also produced by amino-compounds. The inclusion of substances in a liquefied colloid, afterwards dried, produces a hydration effect different from that which results from placing the substance in the water in which the biocolloid may be placed. This fact has wide significance in the physiological action of cell-masses. Renewal or replacement of hydrating solutions may result in pulsations or rapid swellings followed by slow shrinkages or retractions. Gels similar to those entering into living matter may take on structure by which small masses or sections may display 